\title{
BID Gene Product
}

National Cancer Institute

\section{Source}

National Cancer Institute. BID Gene Product. NCI Thesaurus. Code C104459.

A protein encoded by the human BID gene. 